\title{
REPRESENTASI PERUBAHAN SOSIAL DALAM DESAIN KAUS OBLONG BANYUMASAN
}

\author{
Sulyana Dadan \\ Jurusan Sosiologi FISIP Universitas Jenderal Soedirman \\ E-mail: kangdadan_garut@yahoo.com
}

\begin{abstract}
ABSTRAK. Kaus oblong Banyumasan sering menampilkan situasi dan isu aktual dalam setiap desainnya, seperti persoalan pendidikan, politik, budaya dan dinamika sosial kemasyarakatan yang terjadi di Banyumas. Oleh karena itu, tujuan penelitian ini adalah untuk melihat bagaimana representasi perubahan sosial yang dapat terbaca dalam desain kaus oblong Banyumasan. Metode penelitian yang digunakan adalah kualitatif dengan pendekatan semiotik dari Rolland Barthes. Data penelitian berupa desain kaus oblong Banyumasan merk Dablongan Clothing. Data tersebut dianalisis melalui dua tahap penafsiran, dimana penafsiran makna tataran pertama selanjutnya dijadikan pijakan dalam menafsirkan makna tataran kedua. Hasil penelitian menunjukan, bahwa sebagian besar desain kaus oblong Banyumasan merupakan representasi sekaligus kritik terhadap perubahan sosial di Banyumas. Perubahan sosial yang dimaksud antara lain tentang penataan kota yang tidak humanis; perubahan masyarakat agrarais menjadi kota industri; dan gaya hidup masyarakat Banyumas yang adaptif terhadap modernitas dalam hal konsumsi makanan-makanan bergaya barat.
\end{abstract}

Kata kunci: representasi; perubahan sosial; desain kaus oblong

\section{THE REPRESENTATION OF SOCIAL CHANGE IN BANYUMASAN T-SHIRT DESIGN}

\begin{abstract}
Banyumasan T-shirt often displays actual situations and issues in each design, such as issues of education, politics, culture and social dynamics that occur in Banyumas. Therefore, the purpose of this research is to see how a legible representation of social change in the Banyumasan T-shirt design. The research uses is qualitative method a semiotic approach from Rolland Barthes. The form of data is Banyumasan T-shirt designed by Dablongan Clothing. The data is analyzed through two stages of interpretation, where the interpretation of the meaning of the first level is posed as a basis in interpreting the meaning of the second level. The results show that most of Banyumasan's T-shirt design was a representation and critique of social change in Banyumas. The social changes refer to, among other things, the inhumane arrangement of the city; change of agrarian society into an industrial city; and the lifestyle of the Banyumas people who are adaptive to modernity in terms of consumption of western-style foods.
\end{abstract}

Key words: representation; social change; T-shirt design

\section{PENDAHULUAN}

Kaus oblong (T-shirt) telah mengalami transformasi makna dalam dinamika kebudayaan kontemporer. Kaus oblong berkembang menjadi produk fashion yang memiliki ragam makna; dari simbolisasi gaya hidup, status sosial dan afiliasi identitas tertentu. Gambar dan tulisan (teks) dalam kaus oblong juga semakin variatif, tidak hanya bersifat estetis, namun mampu menampilkan realitas sosial-budaya kontemporer yang beragam. Menurut Antariksa (2009: 3) dan Bangsawan (2014: 30), saat ini kaus oblong telah menjadi wahana tanda untuk menyampaikan teks secara terbuka, dari pengalaman, gerakan politik, bisnis, relasi sosial, identitas dan bahkan yang tidak menunjukan identitas si pemakainya.

Kaus oblong juga kerap digunakan sebagai media dalam menyebarkan ideologi dan gerakan sosial. Andrew (2014: 2) mencontohkan, pada 1960-an, kaum hippies di Amerika Serikat (AS) menggunakan kaus oblong sebagai media kampanye untuk mengajak masyarakat dalam menekan pemerintah AS agar segera menghentikan invasi militernya di Vietnam. Contoh lainnya adalah legenda dunia musik yaitu John Lennon yang sering menggunakan kaos bertuliskan "Make Love Not War". Selain itu, kaus oblong dengan desain lambang perdamaian karya Gerald Holtom juga banyak dipakai di berbagai belahan dunia.
Sebagai salah satu jenis budaya populer, peredaran kaus oblong telah merambah ke semua pelosok Indonesia, termasuk Banyumas. Di wilayah ini, bermunculan produsen kaus oblong dengan beragam corak desain yang menunjukan budaya Banyumasan, seperti: falsafah hidup, seni-budaya, bahasa, watak masyarakatnya, tradisi, dan lain-lain. Kaus oblong Banyumasan ini sering menampilkan fenomena sosial-budaya kontemporer yang sedang jadi buah bibir masyarakat. Contohnya Malaysia yang sering mengklaim berbagai kebudayaan dan seni Indonesia, isyu korupsi, dinamika politik lokal, kritik terhadap dunia pendidikan dan lain-lain.

Shodiq, dkk (2014: 23) dan Hariyadi (2016: 6) menyebutkan bahwa sampai akhir 2014, terdapat 17 (tujuh belas) produsen kaus oblong di wilayah Banyumas. Jumlah ini meningkat pesat dari yang hanya satu merk pada tahun 2006-an, yakni kaos Dablongan. Produsen dan merk kaus oblong Banyumasan yang saat ini eksis antara lain: Bhineka Ceria, Kidal Kolektif, Dablongan, Kreasi Inyong, Bengkong, Ngapak, Kuda Lumping, Orange Clothing, Konveksine Inyong, Maning, Bawor, Ice Box, Baloeng Gedhe, Youth Attack, Klinik Rebel, Cablaka dan Domong.

Beberapa contoh tulisan dalam kaus oblong Banyumasan merk Dablongan misalnya; "Mendoan Banyumas, dejaga sing ngati-ngati sedulur, aja nganti diaku-aku wong 
malaysia" (Mendoan Banyumas harus benar-benar dijaga, jangan sampai diklaim oleh Malaysia), "Rika tah meneng bae nglombo, apa maning ngomong” (Kamu itu diam saja sudah bohong, apalagi (kalau sampai) ngomong), "Burit kantor, didelah nang pedaringan jelas kesenengan" (tikus kantor (koruptor), disimpan di tempat penyimpanan beras tentu kesenengan), dan lain-lain.

Teks (tulisan dan gambar) dalam kaus oblong Banyumasan dapat dibaca sebagai ekspresi budaya sekaligus sikap kritis masyarakat Banyumas dalam menyikapi berbagai fenomena sosial-budaya keseharian yang terjadi di sekitarnya. Artinya, berbagai desain kaus oblong Banyumasan sejatinya merupakan potret proses perubahan sosial yang terjadi pada saat kaus tersebut diproduksi. Ragam perubahan sosial tersebut dikemas dengan menggunakan bahasa Banyumasan dan gambar yang selama ini menjadi identitas budaya Banyumas, seperti sosok Bawor, Alun-alun, kopi tubruk khas Banyumas, mendoan dan lain-alin.

Bertolak dari latar belakang di atas, maka penelitian ini akan mengkaji tentang bagaimana representasi perubahan sosial dalam desain kaus oblong Banyumasan. Tujuannya adalah untuk mengetahui dinamika perubahan sosial di wilayah Banyumas yang terekspreksikan dalam salah satu budaya populer yaitu kaus oblong Banyumasan.

\section{METODE}

Metode penelitian yang digunakan dalam penelitian ini adalah kualitatif dengan pendekatan semiotik. Sasaran penelitiannya berupa data tekstual, baik tulisan maupun gambar yang terdapat dalam kaus oblong Banyumasan. Pengumpulan data diawali dengan menyeleksi desain-desain kaus oblong Banyumasan dari merk Dablongan Clothing. Pertimbangannya, merk Dablongan Clothing adalah merk kaus oblong Banyumasan paling populer di Banyumas dan paling banyak menampilkan isu-isu tentang perubahan sosial di Banyumas. Setelah diseleksi, desain terpilih dianalisis menggunakan pendekatan semiotik dari Roland Barthes. Semiotika yang dikembangkan Barthes (1972), lebih menekankan untuk mengungkapkan makna "lain" yang ada dalam teks yang hanya bisa dilakukan melalui metode semiotika tingkat dua atau mitos. Menurut Barthes (1972: 303), mitos berada dalam sistem semiologis tatanan kedua (second-order semiological system). Artinya, apa yang merupakan tanda dalam sistem yang pertama, selanjutnya hanya akan menjadi sekedar penanda dalam sistem yang kedua. Berdasarkan pemahaman tersebut, penelitian ini akan menguaraikan terlebih dahulu makna-makna data tekstual di tataran pertama untuk kemudian dijadikan pijakan dalam menafsirkan makna di tataran kedua.

\section{HASIL DAN PEMBAHASAN}

\section{Analisis Semiotik \\ Desain Alun-alun Purwokerto}

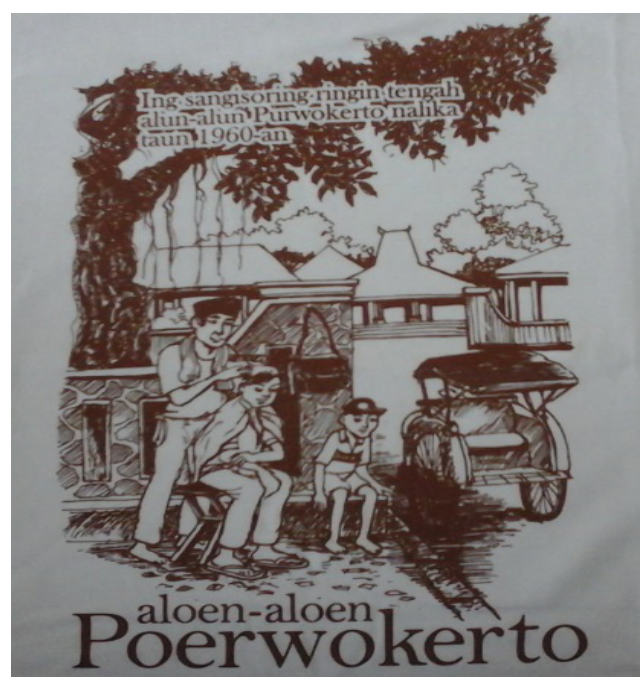

sumber: dokumentasi peneliti, 2017

\section{Gambar 1: desain kaus Alun-alun Purwokerto}

Pada sistem semiotika tataran pertama (denotasi), gambar dan tulisan dalam desain kaus oblong di atas bermakna seorang tukang cukur sedang memotong rambut pelanggannya di bawah sebuah pohon besar. Di dekat tukang cukur ada seorang anak kecil yang sedang duduk dan tidak jauh dari anak kecil itu juga terdapat becak kosong yang sedang parkir. Teks verbal dalam desain kaus oblong di atas berfungsi sebagai penambat (anchorge) yang mengikat makna bahwa beberapa aktivitas yang terlihat di gambar merupakan aktivitas yang biasa atau pernah terjadi di bawah pohon beringin kurung di tengah alun-alun Purwokerto pada tahun 1960-an.

Pada semiotika tataran kedua, desain di atas menawarkan beberapa makna konotatif. Pertama, kegiatan usaha pangkas rambut yang bertempat di bawah pohon berkonotasi dengan jenis usaha yang biasanya dilakukan masyarakat kelas bawah, dimana para pelanggannya juga berasal dari kalangan masyarakat bawah. Kemudian, penanda visual berupa gambar becak biasanya juga berkonotasi dengan kehidupan masyarakat kecil atau bahkan kemiskinan. Jadi, teks visual di atas bermakna bahwa di masa lalu, Alun-alun Purwokerto merupakan salah satu tempat mencari nafkah bagi lapisan masyarakat kelas bawah.

Penanda visual di atas juga bermakna tentang suasana klasik Alun-alun Purwokerto, dimana kala itu terdapat pohon beringin besar yang terletak di tengah alun-alun yaitu beringin kurung yang dijadikan salah satu tempat beraktivitas oleh masyarakat. Penanda pohon beringin kurung yang dipagari tembok menawarkan makna bahwa pemerintah sangat melindungi dan menjaga pohon tersebut. Gambar pohon beringin kurung juga merupakan pesan ikonik berkode karena pohon beringin terkait dengan identitas budaya Jawa. Dalam mitologi 
Jawa, beringin kurung merupakan simbol menyatunya penguasa dan masyarakat, di mana di masa lalu, di bawah pohon beringin kurung sering digunakan sebagai tempat oleh rakyat untuk bertemu dan berkeluh kesah kepada rajanya. Oleh karena itu, di beberapa daerah di Jawa Tengah, beringin kurung dijadikan cagar budaya yang dilindungi oleh undang-undang.

Pada desain di atas juga terdapat gambar kompleks bangunan tradisional berupa beberapa bangunan berbentuk joglo. Secara denotatif penanda ini bermakna sebagai kantor pemerintahan Kabupaten Banyumas pada waktu itu di mana di depan alun-alun terdapat bangunan yang bernama pendopo Si Panji yang biasa digunakan sebagai digelarnya acara-acara resmi pemerintahan dan pertemuan antara pemerintah dengan masyarakat. Penanda kantor pemerintahan ini berkonotasi dengan kekuasaan. Oleh karena itu, aktivitas keseharian masyarakat di Alun-alun Purwokerto dengan latar belakang kompleks kantor pemerintahan merupakan penanda yang memberikan petanda tentang kedekatan antara rakyat dan penguasa pada saat itu. Teks visual di atas menawarkan makna bahwa penguasa pada waktu sangat mengayomi masyarakatnya sehingga memperbolehkan masyarakat untuk mencari nafkah di tengah lapangan alun-alun. Di masa lalu, alunalun memang merupakan pusat kegiatan masyarakat sehari-hari dari perdagangan, kerajinan sampai pendidikan bahkan pertahanan karena sering pula digunakan sebagai tempat latihan para prajurit atau militer.

Jadi, desain kaus oblong di atas merupakan representasi masyarakat Banyumas yang guyub rukun dengan pemerintahnya di masa lalu. Masyarakat kecil dijaga dan dilindungi oleh penguasa Banyumas waktu itu dalam mencari nafkah. Adanya ikon beringin kurung yang dipagar merupakan pesan bahwa pemerintah di masa lalu sangat melindungi beringin kurung yang bernilai sebagai cagar budaya. Oleh karena itu, desain di atas merupakan upaya membandingkan kondisi alun-alun di masa lalu dengan masa kini, sehingga desain di atas sebenarnya merupakan kritik terhadap pemerintah di era sekarang yang telah merombak alun-alun.

\section{Desain Bawor Ranger}

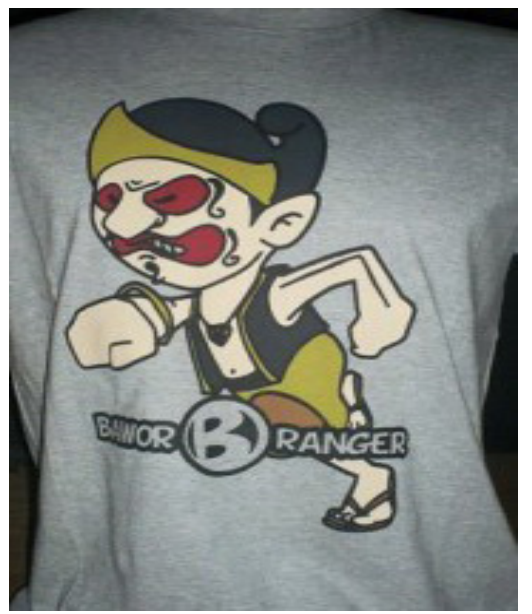

sumber: dokumentasi peneliti, 2017

Gambar 2 . Desain Bawor Ranger
Pada sistem semiotika tingkat pertama, teks visual dan verbal di atas bermakna sesosok wayang orang yang sedang berlari. Ia berlari dengan memejamkan mata dan mulut menyeringai. Teks verbal Bawor Ranger berfungsi sebagai penambat dari teks visual untuk menjelaskan bahwa sosok tersebut adalah Bawor Rangers. Jadi secara denotatif, makna desain di atas adalah Bawor Rangers yang sedang berlari.

Pada sistem semiotika tataran kedua, penanda visual dan verbal di atas menawarkan makna konotatif yang terkait dengan identitas budaya Banyumas. Sosok dalam desain di atas disebutkan sebagai Bawor Ranger. Sosok Bawor, merupakan pesan ikonik berkode karena memiliki kode budaya sebagai maskotnya wong Banyumas di mana beberapa karakternya dianggap mewakili masyarakat Banyumas. Seperti dikatakan Tohari (2014: 38):

"Anadene Bawor, penakawan anak mbarepe Semar, pancen dedhapuk nggo makili wateke wong penginyongan; lugu, apa anane, lan angger wicara ora basa. Kabeh kuwe mertelakna wateke masrakat sing budayane ora nganggo undha-usuk. Lan kiye lewih cocog tumrap alam siki sing dearani alam demokrasi. Mula jan-jane budaya penginyongan siang asale sekang budaya Jawa Kuna kudu dejaga, malah kudu debangun supaya lewih kuat maning".

[adalah Bawor, punakawan anak pertama Semar, memang didaulat mewakili watak masyarakat pangiyongan (Banyumas); yang lugu, apa adanya dan jika berbicara tidak begitu memperdulikan sopan santun. Semuanya itu menggambarkan watak masyarakat yang budayanya tidak menggunakan kaidah etika sopan-santun. Dan ini lebih cocok diwujudkan di era sekarang ini yang dinamakan alam demokrasi. Oleh karena itu, budaya panginyongan yang asalnya bersumber dari budaya Jawa Kuno harus dijaga, bahkan harus dibangun supaya lebih kuat lagi (pen.)]

Olehkarenaitu,penandaBawormerupakankonotator bagi masyarakat Banyumas dengan berbagai kekhasan karakternya tersebut di atas. Namun, penampakan Bawor yang terdapat dalam desain di atas sangat berbeda dengan penampakan Bawor yang selama ini dikenal di Banyumas. Bawor yang dijadikan maskot orang Banyumas adalah Bawor versi wayang gagrak Banyumasan yang memiliki ciri fisik seperti Semar sebagai bapak dari Bawor. Heru Satoto (2008: 201) menyebutkan bahwa Bawor memiliki tubuh yang tambun, pendek, kepalanya bloak, perut bulat, pusarnya bodong, agak bungkuk suaranya berat dan besar. Kemiripan Bawor dan Semar menurut cerita pewayangan versi Banyumasan karena Bawor bukanlah anak biologis dari Semar, tapi merupakan jelmaan dari bayangan Semar yang sengaja diciptakan untuk menemani perjalanan Semar. Dalam desain di atas, Bawor digambarkan tidak bertubuh seperti yang dicitrakan selama ini. Hal ini bisa ditafsirkan bahwa ada perubahan dalam diri Bawor atau bisa jadi menawarkan makna tentang perubahan pada 
karakter wong Banyumas. Meskipun demikian, berbagai aksesoris tradisional yang melekat pada tubuh Bawor dapat bermakna tentang keadaan tidak lepas (kuatnya) sifat-sifat tradisional (khas) yang dimiliki oleh Bawor. Herusatoto (2008: 202) dan Priyadi (2003: 24 dan 2013: 35) menyebutkan selain cablaka, Bawor memiliki sifat sabar, berjiwa ksatria dan cancudan (rajin dan cekatan) sehingga dihormati oleh adik-adiknya.

Petanda perubahan karakter masyarakat Banyumas, dikuatkan dengan adanya penanda lingual/ verbal yakni "Bawor Ranger". Penanda ini secara intertekstualitas mengacu pada sebuah film animasi anak yaitu "Power Rangers". Film ini bercerita tentang sekelompok anak muda di Amerika yang bisa berubah dari manusia biasa menjadi super hero (pahlawan). Perubahan itu biasanya dilakukan ketika ada musuh yang datang dan menyerang kota di mana mereka tinggal. Mereka juga bisa mengendalikan robot raksasa yang berasal dari gabungan kendaraan atau senjata yang mereka miliki.

Jadi, secara konotatif desain Bawor yang berubah menjadi Bawor Ranger di atas dapat dimaknai bahwa masyarakat Banyumas saat ini sedang mengalami perubahan. Perubahan yang dimakasud adalah perubahan karakternya sebagai wong panginyongan dan bisa juga perubahan sosial yang terjadi dalam diri Bawor sebagai bagian dari masyarakat. Artinya, sosok Bawor yang berubah juga memberikan petanda bahwa saat ini sedang terjadi proses perubahan sosial di wilayah Banyumas. Oleh karena itu, aktivitas Bawor Ranger yang sedang berlari juga menawarkan makna tentang masyarakat Banyumas yang sedang berlari mengikuti laju perubahan sosial yang terjadi.

Selanjutnya, dilihat dari ekspresi wajahnya (mata yang dipejamkan dan mulut yang menyeringai), Bawor Ranger yang berlari ini seperti sedang mengalami kelelahan. Hal ini dapat dimaknai, bahwa sebagian masyarakat merasa gagap dengan perubahan yang begitu cepat tersebut sehingga merasa kelelahan. Saat ini, wilayah Banyumas telah menjelma menjadi pusat pertumbuhan ekonomi dan sosial di wilayah Jawa Tengah bagian barat. Masyarakat Banyumas merasa lelah ketika menghadapi perubahan sosial. Atau dengan kata lain, telah terjadi fenomena gegar budaya pada masyarakat Banyumas akibat transformasi dalam kehidupan mereka yang begitu cepat.

Jadi, seluruh desain kaus dengan tema "Bawor Ranger" di atas merupakan representasi tentang wong Banyu-mas yang sedang mengalami perubahan. Perubahan ini terjadi seiring laju perubahan sosial di Banyumas yang begitu cepat. Meskipun demikian, karakter khas wong Banyumas yang cablaka, sederhana, lugas dan lain-lain tetap melekat di tengah gempuran perubahan sosial yang terjadi.

\section{Desain Clebek}

Pada sistem semiotika tingkat pertama, desain di atas memiliki makna sebuah cangkir warna putih yang berisi benda (cair) berwarna hitam. Cangkir tersebut diletakan di atas sebuah tatakan yang juga berwarna putih. Di dekat cangkir, juga terdapat gambar biki kopi bertebaran yang terdapat dalam lingkaran berbentuk donat berwarna cokelat.

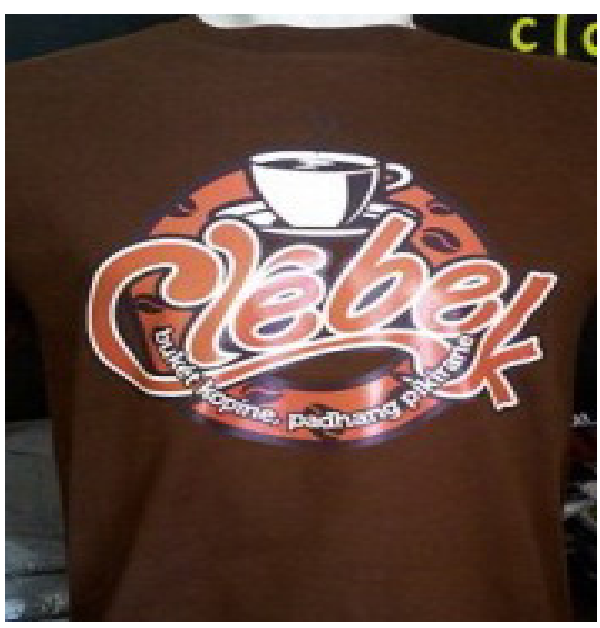

sumber: dokumentasi peneliti, 2017

\section{Gambar 3: Desain Clebek}

Pada semiotika tataran kedua, teks visual cangkir berelasi dengan teks verbal "Clebek" yang ditulis dalam huruf besar. Kata "Clebek" berfungsi sebagai penambat bagi teks visual untuk mengikat makna bahwa yang ada dalam gelas itu adalah kopi khas Banyumas yang disebut clebek atau kopi tubruk. Clebek adalah kopi pahit dengan warna hitam pekat dimana takaran kopinya lebih banyak daripada gulanya. Sementara teks verbal lainnya yakni "bhuket kopine, padhang pikirane" berfungsi sebagai pemancar (relay) bagi teks visual untuk menjelaskan bahwa clebek yang kental (bhuket) memiliki khasiat tertentu yakni mampu membuat pikiran padhang (terang).

Penanda tanda visual berupa segelas kopi yang terlihat masih berasap di atas menawarkan makna bahwa kopi clebek siap saji. Artinya, Clebek bisa dinikmati kapan pun dan bagi siapa pun yang menginginkan pikirannya terang. Pikiran terang adalah kondisi dimana pikiran seseorang yang fresh (segar) karena tidak punya atau terlepas dari berbagai permasalahan yang menguras kerja pikiran (mental). Sebaliknya, pikiran gelap berasosiasi dengan banyaknya atau adanya persoalan yang sulit atau belum menemukan jalan keluarnya. Jadi, berdasarkan frasa dalam teks visual di atas, maka semakin kental dan pahit secangkir clebek, maka akan membuat sebuah permasalahan dapat terselesaikan. Sebaliknya, semakin encer clebeknya, justru membuat sebuah permasalahan menjadi tidak terselesaikan dan membuat pikiran menjadi gelap (kalut). Jadi, bagi wong Banyumas, untuk mengatasi berbagai persoalan yang menguras pikiran, cukup dihadapi dengan santai, yakni minum clebek yang kental, maka segala persoalan tersebut "akan" hilang.

Teks Clebek juga berelasi dengan budaya minum kopi di Banyumas yang sudah berlangsung lama. Biasanya, minum kopi dilakukan ketika melakukan ndopokan membahas persoalan yang serius atau sekedar mengobrol. 
Menurut Herusatoto (2008: 97), ndopokan artinya ngudar rasa atau mengobrol untuk mengeluarkan unek-unek kepada orang lain agar jika ada permasalahan bisa dibagi kepada orang lain untuk mencari solusinya sehingga pikirannya menjadi lebih rileks. Ndopokan dapat juga diartikan sebagai curahan hati (curhat) yang dilakukan ketika sedang berumpul bersama teman atau sanak saudara.

Jadi, desain di atas secara umum menawarkan makna tentang khasiat clebek yang dapat membuat siapa pun yang meminumnya terbebas dari masalah. Makna ini memproduksi makna tentang salah satu sikap masyarakat Banyumas yang nyantai ketika menghadapi sebuah persoalan. Salah satu cara penyelesaian masalah tersebut adalah dengan menikmati clebek. Sikap "kalem" ini merupakan fragmen ideologi dari kultur masyarakat Banyumas yang dablongan.

\section{Kritik Terhadap Perubahan Sosial di Banyumas}

Kaus oblong telah mengalami transformasi luar biasa dan turut andil dalam dinamika kebudayaan kontemporer. Pakaian jenis ini memiliki fungsi dan makna yang sangat beragam. Kaus oblong kadang bisa menciptakan realitas tertentu yang abstrak, menawarkan identitas, menyajikan berbagai hal tentang kearifan lokal, alat ideologis sekaligus terkena komodifikasi. Penelitian Setiawan (2004: 45) memperlihatkan bahwa di era modern, kaus oblong telah berubah menjadi wahana tanda dalam setiap praktik sosial. Teks dan gambar dalam kaus oblong dapat dilihat sebagai sebuah usaha untuk menciptakan realitas sosial secara konkret. Hal ini dapat diartikan bahwa tampilan desain kaus oblong tidak lepas dari konteks sosialnya.

Konteks sosial dari desain kaus oblong bisa dilacak dari kajian Wijana (2003: 23) yang meneliti kaus Dagadu. Wijana menemukan bahwa gaya plesetan yang ditampilkan dalam kaus Dagadu merupakan representasi kearifan lokal masyarakat Yogyakarta yang suka guyon. Temuan hampir serupa diungkapkan Tinarkubo (2006: 102-103) yang juga mengkaji Dagadu, bahwa ada representasi budaya Yogyakarta dibalik desain-desain Dagadu, baik karakter orang maupun ciri khas kota Yogyakarta. Sementara Ayuwuragil dan Efendy (2010), menemukan bahwa kaus oblong Malangan ditujukan untuk menyampaikan solidaritas dan keintiman di antara orang Malang dan Komunitas Aremania, menghibur orang, menyampaikan kritik sosial, memainkan satir untuk orang lain dan mempromosikan budaya Malang. Dadan (2010: 45) meneliti desain kaos dablongan sothen menemukan bahwa ada nilai-nilai budaya Banyumasan yang ingin disampaikan dalam desain kaus tersebut. Nilainilai tersebut sebagian besar adalah karakteristik khas yang menjadi identitas masyarakat Banyumas, antara lain nilai-nilai kejujuran yang dalam bahasa orang Banyumas disebut cablaka.

Teks-teks dalam desain kaus oblong Banyumasan, juga tidak terlepas darikonteks sosialnya, yaknirepresentasi perubahan sosial yang terjadi di wilayah ini. Perubahan yang dimaksud adalah transformasi kehidupan masyarakat di wilayah Banyumas yang saat ini telah menjelma menjadi pusat ekonomi dan perkembangan sosial di wilayah Jawa Tengah bagian barat. Hal ini dibuktikan dengan semakin maraknya pendirian pusat-pusat perbelanjaan, lembaga keuangan dan jasa, perusahaan bertaraf internasional, berbagai tempat hiburan dan lain-lain. Kondisi ini terjadi hampir di semua wilayah eks-karesidenan Banyumas yakni Banyumas, Purbalingga, Cilacap, Banjarnegara maupun Kebumen.

Perubahan sosial di wilayah Banyumas yang signifikan terjadi di Purwokerto yang merupakan ibu kota Kabupaten Banyumas. Saat ini, Purwokerto telah berkembang menjadi salah satu kota perdagangan yang ramai dengan perputaran uang terbesar ketiga di Jateng. Keberadaan lebih dari 30 bank lokal/nasional, 15 pasar tradisional, shopping mall, dan ratusan toko/ruko dapat menjadi indikator dinamisnya aktivitas ekonomi kota Purwokerto. Puluhan hotel berbintang dan penginapan kelas melati yang ada di Purwokerto juga menunjukkan arti penting kota ini sebagai kota transit. Kemudian, keberadaan belasan kampus, baik yang berstatus negeri ataupun swasta, juga semakin menambah semarak kota ini yang dijejali kurang lebih 60 ribu mahasiswa dari berbagai daerah di Indonesia. Banyaknya jumlah mahasiswa membawa efek berantai tidak saja dalam mengembangkan perekonomian kota tapi juga potensi menumbuh kembangkan industri kreatif seperti kaus oblong Banyumasan.

Perkembangan kotaPurwokerto banyak dipotret oleh produsen kaus Banyumasan Dablongan Clothing yang juga memiliki tempat usaha di tengah kota Purwokerto. Salah satunya adalah desain yang bertema Alun-alun Purwokerto. Desain ini, meskipun menampilkan lay out Alun-alun Purwokerto di tahun 1960-an, namun sejatinya merupakan kritik terhadap perombakan alun-alun yang dilakukan pada tahun 2008 di era kepemimpinan Bupati Mardjoko. Desain ini seolah-olah mengajak siapa pun yang melihat desain kaus ini, untuk membandingkan Alun-alun Purwokerto di masa lalu dan masa kini. Lapangan alunalun di masa lalu terbagi menjadi dua, yakni lapangan barat dan timur yang dipisahkan dengan sebuah jalan di tengahnya. Jalan tersebut biasanya merupakan jalur keluar masuk para pejabat atau pegawai pemerintahan. Namun, lay out itu berubah total sejak dirombak. Jalan di tengah alun-alun ditiadakan sehingga lapangan alun-alun menjadi satu, tidak lagi terbagi menjadi dua antara lapangan barat dan timur. Kemudian, dua beringin kurung yang berada di kedua pinggir jalan tengah tersebut juga dipindahkan ke tempat lain. Selain itu, pada awal-awal perombakan, alun-alun dilengkapi dengan videotron, area hot spot,dan menjadi area yang harus bebas dari para Pedagang Kaki Lima (Suara Merdeka, 15/11/ 2008).

Perombakan alun-alun tersebut sempat menuai reaksi negatif masyarakat, khususnya kalangan budayawan 
dan seniman yang mengkhawatirkan hilangnya aspek dan nilai-nilai budaya alun-alun Purwokerto sebagai salah satu identitas khasnya. Kekhawatiran kalangan seniman dan budayawan ini rupanya terbukti. Dalam laporan Kompas edisi 16 Agustus 2010, diberitakan bahwa warga Banyumas khususnya Purwokerto merasa terusik dengan penataan Alun-alun Purwokerto. Semenjak alun-alun diubah dan ditata ulang, tidak ada lagi rasa kedekatan antara masyarakat dan alun-alun itu. Semua digantikan dengan kemewahan semu. Hampir di setiap sudut alunalun Purwokerto terpasang papan larangan; larangan menginjak rumput, larangan bermain sepak bola, larangan berjualan dan lain-lain.

Para seniman dan budayawan pada saat itu menilai, bahwa Alun-alun Purwokerto sudah tidak layak lagi disebut alun-alun, tetapi merupakan sebuah square atau taman kota. Menurut mereka, secara fisik proses penataan Alun-alun Purwokerto telah meninggalkan sisi tradisonal sekaligus mengabaikan persoalan lingkungan. Hal ini dapat dilihat dari dihilangkannya karakter khas tradisional alun-alun yakni dibuangnya dua beringin kurung dan digantikan benda lain sebagai simbol modernitas yakni adanya videotron dan area hotspot. Padahal, alun-alun (sebagaimana di kota-kota di Pulau Jawa lainnya) mempunyai beberapa fungsi. Selain sebagai identitas kota pemerintahan Jawa, alun-alun juga berfungsi sebagai ruang publik, paru-paru kota dan bangunan cagar budaya. Perombakan alun-alun, telah menghilangkan beberapa fungsi di atas, sehingga wajar jika ada beberapa elemen masyarakat yang kecewa terhadap penataan alun-alun.

Kondisi Alun-alun yang berubah ini pula yang menjadi konteks dalam desain dengan tema "Alun-alun Purwokerto". Desain tersebut mengilustrasikan bagaimana kondisi Alun-alun di masa silam yang berfungsi sebagai tempatmasyarakatkecilmencarinafkah. Bahkan, penguasa atau pemerintah pada waktu itu pun sangat mengayomi masyarakat kecil dengan membiarkan mereka untuk beraktivitas di Alun-alun. Sementara saat ini, masyarakat yang ingin beraktivitas di alun-alun Purwokerto terutama PKL harus kucing-kucingan dengan petugas Satpol PP. Para PKL ini terutama mereka yang direlokasi ke tempat lain, namun ternyata di tempat baru tersebut banyak dari mereka yang gulung tikar karena dagangannya tidak laku. Akhirnya, sebagian dari mereka kembali ke alun-alun meski dengan resiko harus berhadapan dengan Satpol PP.

Isu perubahan sosial di Banyumas juga dapat dipotret dari perubahan masyarakatnya yang tercermin dalam desain Bawor Rangers. Seperti diketahui, Bawor merupakan maskotnya orang Banyumas karena tokoh ini dianggap mewakili karakter masyarakat Banyumas. Bawor digambarkan hidup dalam kesederhanaan, lugu, glogok soar (mengemukakan apa saja yang diketahui tanpa menimbang efek positif atau negatifnya), nrima ing pandum dan cablaka/blakasuta (Priyadi, 2007: 15). Karakter Bawor tersebut bisa jadi merupakan identitas sub-etnik Banyumas sebagai bagian dari Budaya Jawa.
Menurut Snanfi (2018: 128), identitas etnik bisa muncul karena adanya kesamaan ikatan primordial, martabat dan bahasa dalam sebuah kelompok etnis.

Desain Bawor Rangers, muncul dalam konteks terjadinya perubahan karakter/ identitas etnik masyarakat Banyumas akibat terjadinya perubahan sosial. Bawor Ranger yang berelasi dengan sosok Power Rangers yang selalu bertransformasi atau berubah ketika ada musuh yang datang kepadanya, bisa jadi merupakan konteks di mana masyarakat Banyumas juga sedang mengalami perubahan karakter karena ada "musuh" yang datang. Namun, "musuh" wong Banyumas bukan alien (seperti digambarkan dalam film Power Rangers), tapi serbuan budaya luar yang coba di lawan oleh wong Banyumas. Perubahan dilakukan untuk membela diri. Dalam konteks ini, masyarakat Banyumas berupaya berubah untuk menyesuaikan diri dengan perubahan yang sedang terjadi di lingkungan sekitarnya. Hal ini juga mengindikasikan bahwa ada nilai budaya yang ingin dipertahankan oleh masyarakat Banyumas. Hindaryatiningsih (2016: 108) menyatakan, nilai budaya merupakan seperangkat keyakinan yang berpengaruh terhadap perilaku dan sikap sebuah kelompok masyarakat. Urgensi nilai budaya ini juga tampak relevan dengan konteks desain ini, dimana nilai-nilai budaya Banyumas seperti sikap cablaka atau kejujuran yang melekat dalam diri Bawor sebagai perwakilan masyarakat Banyumas dipertahankan sekuat tenaga dalam dinamika perubahan sosial yang terjadi di Banyumas.

Perubahan sosial lainnya juga dapat dilihat dengan mencermati perubahan gaya hidup masyarakat. Tanto (2014: 54) menyebutkan, bahwa di masa lalu, khususnya di era tanam paksa, Banyumas merupakan masyarakat agraris dan penghasil beberapa komoditi pertanian. Namun, sekarang wilayah Banyumas seolah telah menjadi pasar dalam bagi berbagai produk budaya populer yang terkait dengan gaya hidup. Salah satunya adalah minum kopi. Saat ini, banyak sekali cafe dan kedai kopi di wialayh Banyumas. Di berbagai sudut kota Purwokerto terdapat belasan kedai kopi yang menjual berbagai produk kopi dari seluruh nusantara, seperti kopi gayo, kopi lampung, kopi papua dan lain-lain. Laporan Suara Merdeka (18/01/ 2017: 21) menyebutkan bahwa saat ini di wilayah Banyumas Raya bermunculan kedai kopi dengan berbagai karakteristiknya, antara lain Kabupaten Banyumas 50 kedai, Purbalingga (12), Banjarnegara (8), Cilacap (8) dan di Kebumen/ Gombong (3). Kedai-kedai kopi ini muncul sejak tahun 2000-an dengan pelannggan mulai dari masyarakat umum, mahasiswa dan para sesepuh penikmat kopi di Banyumas.

Mengkonsumsi kopi tidak lagi sekedar minum kopi, tetapi berkaitan dengan gaya hidup tertentu karena menikmati kopi berelasi dengan di mana dan jenis kopi apa yang dikonsumsi serta berapa harga yang harus dibayar untuk segelas kopi. Pada Akhirnya, mengkonsumsi kopi bukan lagi bicara tentang cita rasa kopi, tapi sarana 
kontestasi status konsumen kopi dengan menunjukan perbedaan selera dalam mengkonsumsi kopi. Hal inilah yang menjadi konteks desain "Clebek" yang mencoba meniru sekaligus melawan budaya populer dengan memunculkan citra visual maupun verbal tentang Celebek. Teks ini seolah ingin menunjukan tentang eksistensi Clebek yang tidak kalah dengan kopi lainnya. Bahkan di beberapa kedai kopi, Clebek menjadi primadona dan pilihan konsumennya. Hal ini bisa jadi merupakan konteks politis untuk memperlihatkan bahwa clebek yang dulu hanya dikonsumsi di desa-desa oleh orang tua, kini kopi tersebut naik kelas karena dapat dikonsumsi di kedaikedai kopi dengan harga yang tidak murah.

\section{SIMPULAN}

Berdasarkan paparan dalam pembahasan di atas, dapat disimpulkan beberapa hal sebagai berikut. Pertama, desain kaus oblong di atas merupakan representasi perubahan sosial yang terjadi di wilayah Banyumas di era sekarang atau antara 2008 sampai dengan 2016. Kedua, beberapa perubahan sosial yang dipotret dalam desain kaus oblong di atas adalah tentang penataan kota di wilayah Purwokerto yang dianggap kurang humanis bagi sebagian masyarakat, khususnya seniman dan budayawan. Selain itu, juga terdapat potret perubahan sosial masyarakat Banyumas yang mulai berubah dari agraris menjadi kota industri dan menyebabkan sebagian masyarakatnya mengalami gegar budaya menghadapi perubahan sosial yang begitu cepat. Terakhir, adalah perubahan sosial dalam gaya hidup masyarakat Banyumas yang cenderung menerima gaya hiduap urban dalam mengkonsumsi makanan dan minuman gaya barat yang ditunjukan dengan menjamurnya kedai-kedai kopi berharga mahal.

\section{DAFTAR PUSTAKA}

Andrew, T.V. (2014). Kaos Oblong: Menggugat Kemapanan dan Mengubah Masa Depan. http:// http://www.kabarindonesia.com/berita.php? pil $=12 \& \mathrm{dd}=\mathrm{Kaos}+$ Oblong $\% 3 \mathrm{~A}+$ Menggugat + Kemapanan+\%26+Mengubah+Masa+Depan\&dn =20140519134909 (akses 22 Maret 2015).

Antariksa.( 2009). Menjadi Modern dengan Kaos Oblong. News Letter Kunci, No. 4 Maret 2009, hal: 3-6.

Ayuwuragil, K. \& Effendy, G. (2013). Malangan T-Shirts Language Play as Malangese Identity. dalamh. ttps://www.academia.edu/6824506/Malangan_T_ Shirt_Language_as_Malangese_Identity. (akses 28 November 2017)
Bangsawan, A. (2014). Lokalitas Konten dalam Visual Kaus Cak-Cuk Surabaya. Artkita, 1, (01), 29-37.

Barthes, R. (1972). Mythologies. New York: Hill and Wang.

Dadan, S.(2010). Politik Identitas Kaos Dablongan. Laporan Penelitian Riset Pemula, Purwokerto: LPPM UNSOED.

Hariyadi. (2007). Globalisasi dan Politik Identitas; Mencari Banyumas sebagai "Jawa yang Lain". Swara Politika, 10, (01), 5-15.

Hariyadi. (2016). Yang Muda Yang Kreatif: Perkembangan Disain Kaus di Banyumas. News Letter Yayasan Biennale Yogyakarta, 4, (3), 4-9.

Herusatoto, B. (2008). Banyumas: Sejarah, Budaya, Bahasa dan Watak. Yogyakarta: LkIS.

Hindaryatiningsih. (2016). Model Proses Pewarisan Nilainilai Budaya Lokal dalam Tradisi Masyarakat Buton. Sosiohumaniora, 18, (2): 108-115.

Priyadi, S. (2003). Beberapa Karakter Orang Banyumas. Bahasa dan Seni, 31, (1), 14-35.

Priyadi, S. (2007). Cablaka Sebagai Inti Model Karakter Manusia Banyumas. Diksi, 14, (1), 11-18.

Priyadi, S. (2013). Sejarah Mentalitas Banyumas, Yogyakarta: Penerbit Ombak.

Setiawan, A.H. (2004). T-Shirt Sebagai Media Tanda. Thesis pada Program Studi S2 Sosiologi FISIPOL Universitas Gadjah Mada, Yogyakarta: UGM.

Shodiq, D., Restuadhi, H. dan Hariyadi. (2014). Menata Gelombang Ekonomi Keempat: Perluasan Jaringan Kerja sebagai Model Pemberdayaan dan Pengembangan Subsektor-subsektor Industri Kreatif di Banyumas dan Sekitarnya. Laporan Penelitian Riset Institusional Jurusan Sosiologi FISIP Unsoed.

Snanfi, F.L, Darwin, M., Setiadi \& Ihkwan, H. (2018). Politik Identitas Etnik Asli Papua Berkontestasi dalam Pemilihan Kepala Daerah di Kota Sorong. Sosiohumaniora, 20, (2), 122-131.

Tohari, A. (2014). Clamit. Majalah Ancas, edisi 54/ tahun V/ Oktober 2014, hal: 38.

Wijana, I.D.P. (2003). Wacana Dagadu, Permainan Bahasa dan Ilmu Bahasa. Pidato Pengukuhan Jabatan Guru Besar pada Fakultas Ilmu Budaya Universitas Gadjah Mada Yogyakarta, 27 Februari 2003. 